Corrigendum

\title{
Corrigendum to "Macroautophagy and Selective Mitophagy Ameliorate Chondrogenic Differentiation Potential in Adipose Stem Cells of Equine Metabolic Syndrome: New Findings in the Field of Progenitor Cells Differentiation"
}

\author{
Krzysztof Marycz, ${ }^{1,2}$ Katarzyna Kornicka, ${ }^{1,2}$ Jakub Grzesiak, $^{2}$ Agnieszka Śmieszek, ${ }^{1}$ and \\ Jolanta Szlapka ${ }^{1}$ \\ ${ }^{1}$ Electron Microscopy Laboratory, The Faculty of Biology and Animal Science, Wroclaw University of Environmental and Life \\ Sciences, Wroclaw, Poland \\ ${ }^{2}$ Wroclaw Research Centre EIT+, Wroclaw, Poland \\ Correspondence should be addressed to Krzysztof Marycz; krzysztofmarycz@interia.pl
}

Received 10 May 2017; Accepted 24 May 2017; Published 27 July 2017

Copyright (c) 2017 Krzysztof Marycz et al. This is an open access article distributed under the Creative Commons Attribution License, which permits unrestricted use, distribution, and reproduction in any medium, provided the original work is properly cited.

In the article titled "Macroautophagy and Selective Mitophagy Ameliorate Chondrogenic Differentiation Potential in Adipose Stem Cells of Equine Metabolic Syndrome: New Findings in the Field of Progenitor Cells Differentiation" [1], an acknowledgment should be added as follows:

\section{Acknowledgments}

This publication was supported by Wrocław Centre of Biotechnology, programme Leading National Research Centre (KNOW) for years 2014-2018.

\section{Reference}

[1] K. Marycz, K. Kornicka, J. Grzesiak, A. Śmieszek, and J. Szłapka, "Macroautophagy and selective mitophagy ameliorate chondrogenic differentiation potential in adipose stem cells of equine metabolic syndrome: new findings in the field of progenitor cells differentiation," Oxidative Medicine and Cellular Longevity, vol. 2016, Article ID 3718468, 18 pages, 2016. 


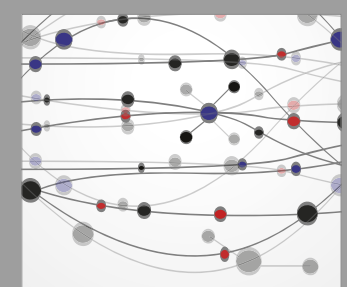

The Scientific World Journal
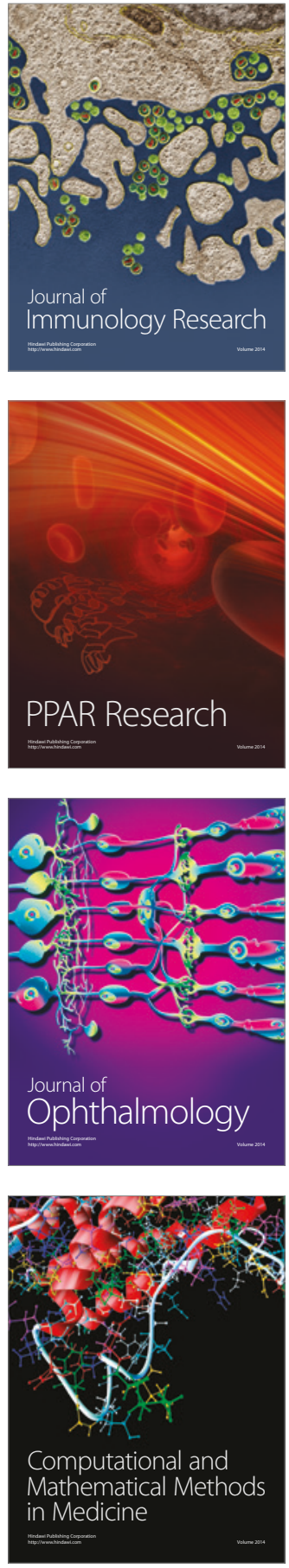

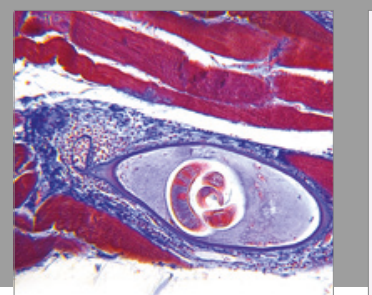

Gastroenterology Research and Practice
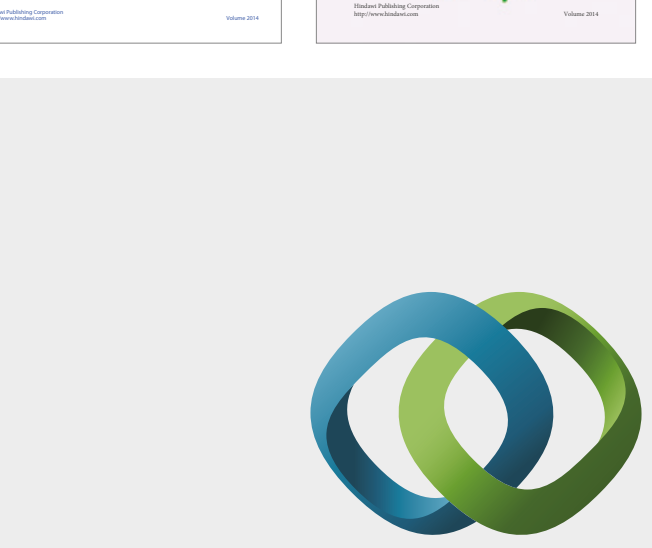

\section{Hindawi}

Submit your manuscripts at

https://www.hindawi.com
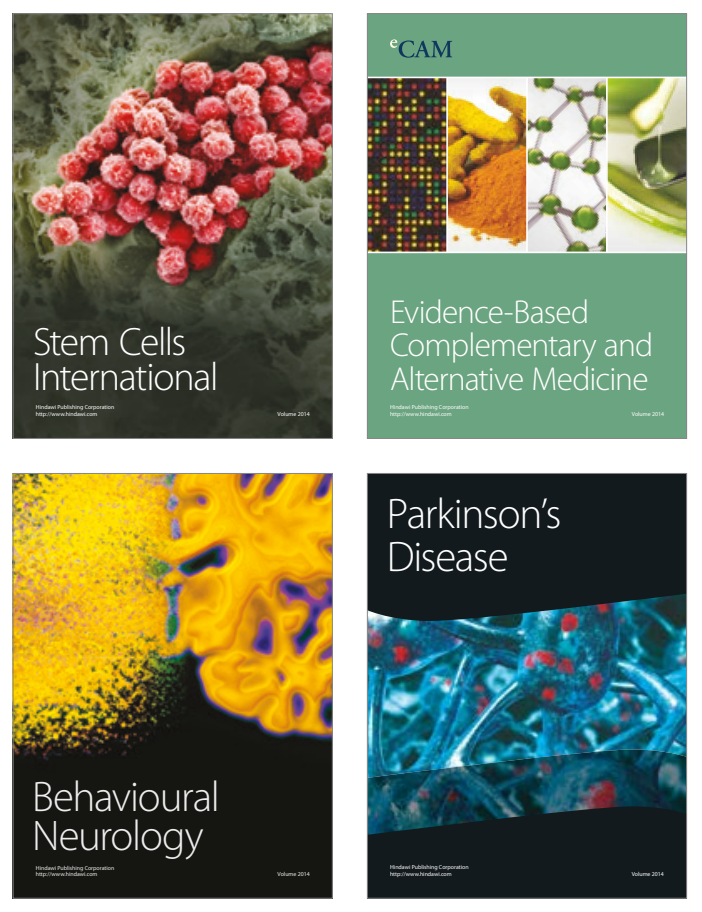
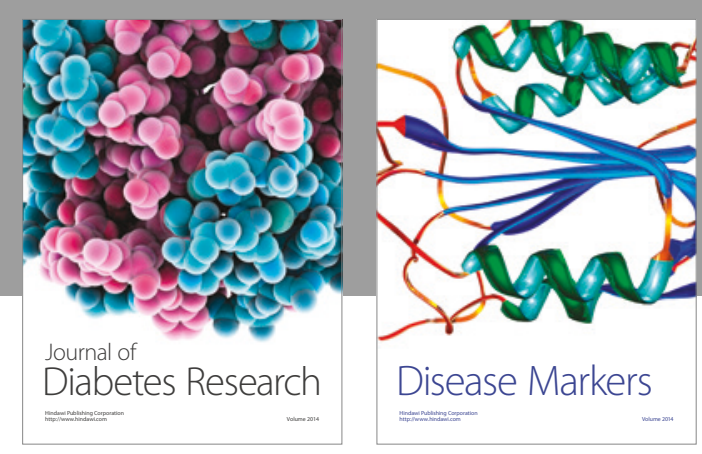

Disease Markers
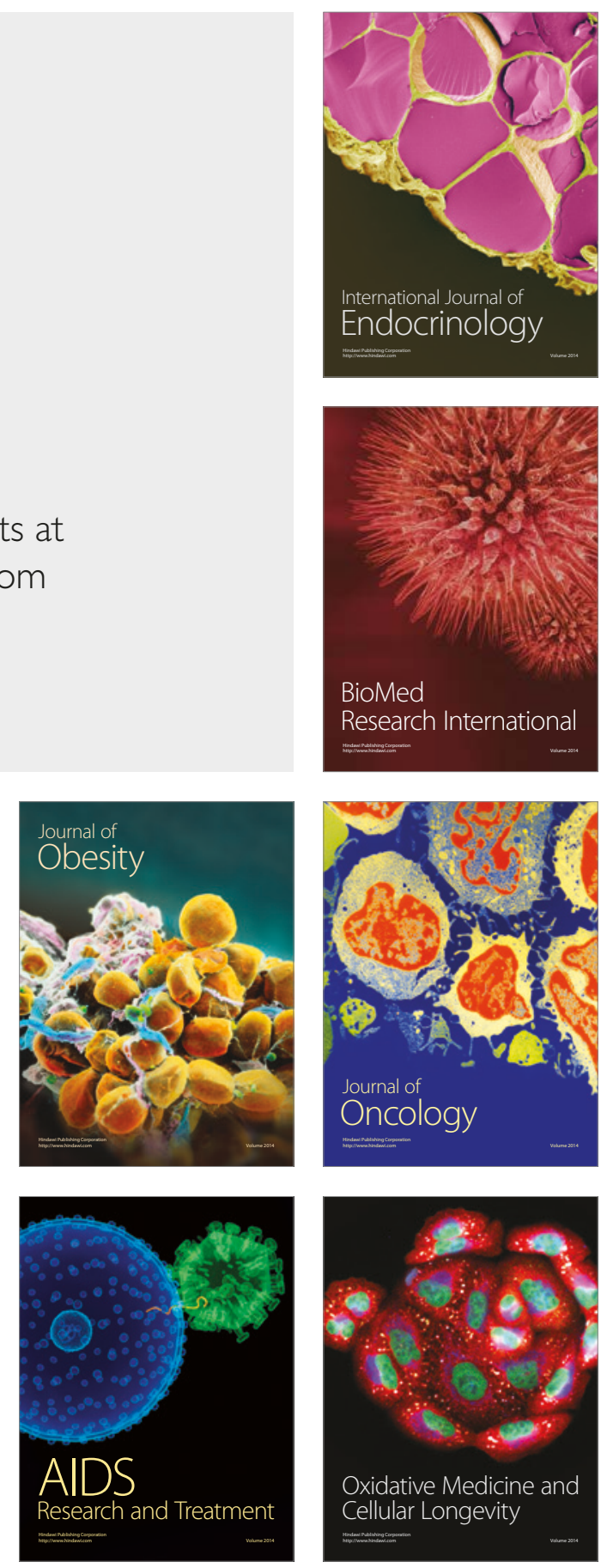